\title{
Motivasyon ile Yaratıcılığın Ortaokul Öğrencilerinde Bilişsel Beceriler Çerçevesinde İncelenmesi
}

\author{
Gülten ÜNAL \\ Ankara Yıldırım Beyazıt Üniversitesi \\ gunal@ybu.edu.tr \\ ORCID: 0000-0003-1000-952X \\ Hüseyin Zahid CAMBAZ \\ Ankara Y1ldırım Beyazıt Üniversitesi \\ zahidcambaz@gmail.com \\ ORCID: 0000-0003-0583-5309 \\ Ece Ceren AKKAYA \\ Ankara Yıldırım Beyazıt Üniversitesi \\ ececeren96@gmail.com \\ ORCID: 0000-0003-3031-9509
}

Araştırma Makalesi

Geliş Tarihi: 30.10.2020

Revize Tarihi: 16.10.2021

DOI: $10.31592 /$ aeusbed.818521

\section{Atıf Bilgisi}

Ünal, G., Cambaz, H. Z. ve Akkaya, E. C. (2021). Motivasyon ile yaratıcılığın ortaokul öğrencilerinde bilişsel beceriler çerçevesinde incelenmesi. Ahi Evran Üniversitesi Sosyal Bilimler Enstitüsü Dergisi, 7(3), 918-935.

\section{ÖZ}

$\mathrm{Bu}$ araştırmanın amacı, çocuklarda yaratıcılık ile motivasyonun karmaşık bellek becerisi bağlamında incelenmesidir. Araştırmada, gönüllü dokuz ebeveyn ve bu ebeveynlerin çocukları ile nitel görüşmeler gerçekleştirilmiş ve yalnızca çocuklara nicel testler uygulanmıştır. Nitel görüşmelerde hem çocuklara hem de bu çocukların ebeveynlerine, çocukların ders çalışma süreçlerindeki içsel ve dışsal motivasyon araçları sorulmuştur. Ayrıca, bu araçların çocuklar, aileler ve öğretmenler tarafından nasıl uygulandığı ve ilgili araçların etkililik düzeylerinin araştırılması da hedeflenmiştir. Çalışmada ek olarak çocukların karmaşık çalışma belleği ve yaratıcılık seviyeleri de ölçülmüştür. Çalışma bulguları, orta okul dönemindeki çocuklarda bilişsel yeteneklerin motivasyon ve yaratıcılığa kısmen de etkili olduğuna işaret etmiştir. Yönetici bellek süreçleri ile motivasyonun bireyin hedefine yönelik davranışları belirlediği düşünüldüğünde, yaratıcıllı̆ın da bu kavramlarla ele alınması önemlidir. Bunlara ek olarak, araştırmanın sonucunda motivasyon bütünlüğü, aile desteği, çocuğun derse yönelik tutumu ve öğretmen etkisi, farkındalık ve referans farklılıkları, ödül toleransı ile karmaşık durumlar ve olumsuz tavırlar önemli temalar olarak ortaya çıkmıştır.

Anahtar Kelimeler: Motivasyon, yaratıcılık, bilișsel beceriler, karmașık bellek.

\section{Investigation of Motivation and Creativity in the Framework of Cognitive Skills in Secondary School Students}

\begin{abstract}
This study aims to examine the creativity and motivation of children in the context of cognitive skills. The study was carried out with the method of qualitative interviews with nine volunteered parents and their children and also quantitative tests were applied to the children. In the study, qualitative interviews were conducted with nine volunteer parents and their children. In qualitative interviews, both the children and their parents were asked about children's internal and external motivation tools during studying their courses. In addition, how these tools are applied by children, families and teachers and the effectiveness levels of the related tools were investigated. The study also measured children's complex working memory and creativity levels. The findings of the study indicated that cognitive abilities are partly effective on motivation and creativity in children in the middle school period. Considering that executive memory processes and motivation determine the behaviors of the individual, it is important to consider creativity with these concepts, as well. In addition, as a result of the research, motivational integrity, family support, child's attitude towards the lesson and teacher influence, awareness and reference differences, reward tolerance, complex situations and negative attitudes emerged as important themes.
\end{abstract}

Keywords: Motivation, creativity, cognitive skills, complex memory.

\section{Giriş}

Yaratıcılık, belirli bir zaman-mekân içerisinde, sosyal ve kültürel çerçevede meydana gelen ve en azından onu yaratan bireyler için orijinal, yararlı, etik ve arzu edilen soyut veya somut sonuçlara 
yol açan (hem zihinsel hem de fiziksel) faaliyettir (Kampylis, Berki ve Saariluoma, 2009). Yaratıcıllğa doğal açıdan bakan görüşler, yaratıcılığın her yerde ve her zaman gerçekleşebileceğini belirtmektedirler. Bu görüş herkesin yaratıcı bir birey olarak doğduğu ve yaratıcı potansiyele sahip olduğunu ve ayrıca çevrenin, bir bireyin yaratıcılı̆̆ının destekleneceğini ya da engelleneceğini hususunda önemli bir rol oynadığını ileri sürmektedir (Mansilla, 2010). Tüm bunların yanı sıra, bazı insanlar özel bir yaratıcı zekâ ile doğmuş olsalarda, her bireyin kendi kişisel yaratıcılığını geliştirilebileceğine inanılmaktadır (Davis ve Rimm, 2004).

Yaratıc1lık genel anlamda bilimsel ve sanatsal yaratıcılık olarak ele alınabilir. Temel olarak, bilimsel yaratıcılık yeni problemleri bulma ve çözme ile hipotez formüle etme yeteneği iken; sanatsal yaratıcılık, yaşamın veya duyguların yeni bir temsilini verebilen ve genellikle önceki bilgilerimizden bir miktar ekleme içeren bir yaratıcılık türüdür (Liang, 2002). Yaratıcılık kavramı ise iki önemli süreçle açıklanabilir: Iraksak düşünme ve aktarım yeteneği. Iraksak düşünme, farklı açılara kadar uzanan düşünmeyi ve birçok türde fikir üretmeyi içermektedir. Iraksak düşünme çocukluk dönemli boyunca durağandır. Aktarım yeteneği ise; bilgiyi tekrardan düzenlemeyi, geleneksel düşünme yolları kurmayı ve yeni düşünce yolları üretmeyi içermektedir (Russ ve Fiorelli, 2010). Bu yetenekler bu araştırmada da olduğu gibi Torrance'in Yaratıcılık Testi (Torrance, Ball ve Safter, 1992) ile ölçülebilmektedir.

Yaratıcılık; kişiliğe, çevreye ve kişinin bilişsel yeteneklerine bağlı olan faktörlerden etkilenebilmektedir (Simonton, 2000; 2009). Bireyin gelişimsel sürecinde ailenin ebeveynlik tutumları (Miller, Lambert ve Speirs-Neumeister, 2012) ailenin bireydeki yaratıc1lkla ilgili kişilik özelliklerini geliştirebilecek tutumlarının olması (Siegelman, 1973) çocuklarda yaratıcılığı etkileyen faktörlerden bazılarıdır. Ayrıca, ailenin çocukla geçirdiği zaman, bu zamanı nasıl değerlendirdikleri ve beraber oynadıkları oyunlar da çocuğun yaratıcılık düzeyi üzerinde oldukça etkili olabilmektedir (Bishop ve Chace, 1971).

Bilişsel kavramlardan hafizayı güncelleyebilme ile baskılama yeteneği (Benedek, Jauk, Sommer, Arendasy ve Neubauer, 2014) ve yönetici fonksiyonların işlevselliği (Beaty, Silvia, Nusbaum, Jauk ve Benedek, 2014) ise yaratıcılıkla ilgili olan bilişsel unsurlardır. Bilişsel kapasitenin gelişmişliği (Guilford, 1957; Simonton, 2010), çalışma belleği (Vandervert, Schimpf ve Liu, 2007), bilişsel esneklik (de Dreu, Nijstad ve Baas, 2011), odaklanmış dikkat (Vartanian, 2009) ve akademik başarı da (Park ve Yoon, 2004) ayrıca bireyin yaratıcı olmasında büyük öneme sahiptir.

Yaratıc1lık gibi bireyin bilişsel ve gelişimsel sürecinde önemli olan bir diğer faktör de motivasyondur. Motivasyon, bu araştırma içerisinde akademik motivasyon olarak ele alınmıştır ve öğrencinin kendi isteği doğrultusunda kendisini öğrenme sürecine katması olarak değerlendirilmiştir. $\mathrm{Bu}$ araştırmada, motivasyon ve yaratıcılı̆̆ın bilişsel bir beceri olan karmaşık çalışma belleği ile ele alınması amaçlanmıştır.

\section{Yaratıcılık, Motivasyon ve Ödül}

Yaratıcı bireylerde olması gereken özellikler zihinsel beceri, bilgi, düşünme tarzı, belirli kişilik özellikleri, motivasyon ve çevresel etkenler olarak sıralanmıştır (Chien ve Hui, 2010; Sternberg, 2005). Bu araştırmada ana değişkenlerden biri olarak ele alınan motivasyon ise yaratıcı bireylerde sıklıkla görülebilmektedir (Feldhusen, 2005; Hennessey, 2001; Isbell ve Raines, 2003; Rowe, 2007). Motivasyon, bireyin hayatta aktif halde devam edebilmesini sağlayan bir kavramdır ve içsel ve dışsal olmak üzere ikiye ayrılmaktadır. İçsel motivasyonda birey dışsal ödül beklemeksizin içsel odaklı bir güdülenme süreci geçirmektedir. Öte yandan, dışsal motivasyonda birey dişsal ödüllerle harekete geçmektedir (Ormrod, 2012; Ryan ve Deci, 2000).

Bireyin motivasyon stillerinin farklı olması, bahsedilen işteki kontrolün kimde olduğuna bağlı olarak değişebilmektedir. Örneğin, bireyin kontrolün dişsal faktörde olduğunu düşünmesi dişsal motivasyon ile bağlantılı iken, kontrolün kendisinde olduğunu düşünmesi motivasyonun içe yönelik olması ile ilişkili bulunmuştur (Rotter, 1966). Ayrıca, öz-belirleme motivasyonun içe veya dışa dönük 
olmasıyla beraber, öğrenmenin üzerinde de doğrudan bir etkiye sahip olduğu görülmektedir (Rigby, Deci, Patrick ve Ryan, 1992).

Ödüller, ilişkili olduğu sonuçları güçlendirmek için kullanılan araçlardır. Eğer ödül; ödülü alan birey tarafından değerli olarak görülürse ve ödül ile elde edilen sonuç arasında doğru bir ilişki kurulabilirse, ödülün yaratıcılığı artıracağı düşünülmektedir. Genel olarak bulgular; yaratıcılık için verilen ödülün yaratıcılığ 1 artırdığı, fakat yüksek performans için verilen ödülün yaratıcılı̆̆ 1 yalnızca belli bir noktaya kadar artırabildiğini bulgulamıştır (Eisenberger ve Selbst, 1994).

Ortaokul öğrencilerinin algıladıkları sosyal desteğin içsel ve dışsal motivasyonu pozitif yönde yordadığı bulunmuştur (Tulunay-Ateş, 2016). Ayrıca, yine ortaokul çocuklarının dışsal motivasyonunun öğrenim düzeyine göre, içsel motivasyonunun ise cinsiyet, öğrenim ve akademik başarı düzeyine göre farklılaştı̆̆ bulunmuştur (Çolak ve Cırık, 2015). Öğrencilerin motivasyonları arttıkça bilimsel yaratıcılıkları da artmaktadır (Deniş-Çeliker, Tokcan ve Korkubilmez, 2015). Bu bilgiler doğrultusunda, bu araştırmada içsel ve dışsal motivasyonun yaratıcılık ile ilişkisinin incelenmesi amaçlanmaktadır.

\section{Yaratıcılığın Gelişimi}

Çocuklarda yaratıcılık bir yaşından itibaren hayal gücü ile başlamaktadır (Argun, 2004). Artan fiziksel ve zihinsel etkinliklerle birlikte çocuklar oyun oynayarak yaratıcılıklarını deneyimleyebilirler. İki-dört yaş arasında, gelişen kelime dağarcıkları çocukların artan merakı ile birleşerek yaratıcıllı̆ın gelişmesine olanak sağlar. Dört-altı yaş arasında artık plan yapabilen çocuklar etraflarındaki kültürün onlara sunduğu sembollerle öykü, resim ve oyun gibi yaratıcı ürünler vermeye başlayabilirler (Argun, 2004; Ömeroğlu ve Turla, 2001). Altı-sekiz yaşları arasında formal eğitime başlamaları nedeniyle de çocukların yaratıcılık seviyelerinde düşüşler gözlenebilir. Sekiz-on yaşları arasında çocukların yaratıcılık seviyesi tekrardan artmaktadır (Çakmak, 2005). On-on iki yaşları arasında ise, keşfetme sürecine devam eden çocuklar bu dönemlerinde genel anlamda her şeyi yaparak denemeye çalışırmaktadırlar (Çağatay-Aral, 1990). Son olarak on üç-on dört yaşları arasında çocuklar en yaratıcı dönemlerindedir ve devam eden yıllarda çocukların yaratıcılıkları ya kısmen düşmekte ya da bu düzeyde devam etmektedir (Güleryüz, 2001). Tüm bu bilgiler çerçevesinde, bu araştırmada çocukların yaratıcılıklarının en yüksek seviyesine gelmeye başladığı ve fakat duraksamadığı yaş aralığı olan 11 ile 13 yaş arasındaki ortaokul öğrencileri ile çalışılmıştır.

\section{Yaratıcılığın Ölçülmesi}

Yaratıcılığı ölçmek için literatürde birçok ölçüm aracı bulunmaktadır (Said-Metwaly, Kyndt ve Noortgate, 2017). Yüzden fazla farklı yaratıcılık çalışmasının taranması ile gerçekleştirilen bir araştırmada yaratıcılık ölçümlerinin en s1k olarak $(\% 52,58)$ yaratıcılıkla ilgili olan yeteneklerin bulunduğu yaratıcılık sürecini ölçtüğü bulunmuştur. Bunu bireyin yaratıcı kişiliğini ölçen yaklaşım $(\% 28,87)$ takip etmekte, sonrasında ise bireyin ürettiği yaratıcı ürün yaklaşımı $(\% 14,43)$ gelmektedir. Son olarak ise içinde bulunulan çevrenin rolünün incelendiği baskı yaklaşımı $(\% 4,12)$ yaratıcılık ölçümü olarak kullanılabilmektedir (Said-Metwaly vd., 2017). Genel olarak araştırmalar saha çalışmaları, ölçek kullanımı, görüşmeler ve testler üzerinden yürütülmektedir (Park, Chun ve Lee, 2016). Bu çalışmada ise, yaratıcılık bu kavramı ölçen bir çizim testi üzerinden ölçülecektir.

$\mathrm{Bu}$ araştırmanın amacı, çocukların kendileri ve aileleri açısından (içsel ve dişsal) motivasyon süreçlerinin, çocukların yaratıcılık ve karmaşık bellekleri ile olan ilişkilerini detaylı bir şekilde incelenmesidir. Araştırmanın hipotezi, içsel motivasyon seviyesi yüksek olan çocukların yaratıcılık ve karmaşık bellek seviyelerinin yüksek olacağını öngörmektedir.

\section{Yöntem}

Bu bölümde, araştırmanın deseni, çalışma grubu, veri toplama araçları, verilerin toplanması ve analizi ile araştırma etiği ile ilgili bilgiler aktarılmıştır. 


\section{Araștırma Deseni}

$\mathrm{Bu}$ araştırmada nitel araştırma deseni türlerinden durum çalışması kullanılmıştır. Araştırmada yar1 yapılandırılmış nitel görüşme tekniği ile gönüllü katılımcı anne ve çocuklara doğrudan sorular yöneltilmiştir. Ayrıca, katılımcı çocuklara nicel yöntemlerden bilişsel iki farklı test (dinleme ve çizme etkinliği içeren) uygulanarak nitel araştırma deseninin nicel verilerle de desteklenmesinin sağlanması amaçlanmıştır.

\section{Çalıssma Grubu}

$\mathrm{Bu}$ araştırmanın örneklemini, amaçlı ve kartopu örnekleme yöntemi ile Ankara'nın farklı bölgelerinde yaşayan orta sosyoekonomik sınıftan gönüllü 9 anne ve bu annelerin ortaokul öğrencisi olan 9 çocuğu (6 erkek) oluşturmaktadır. Annelerin yaşları 33-49 $(X=39, S s=4.71)$, öğrencilerin yaşları ise 11-13 $(X=11.89, S s=.74)$ arasında değişmektedir. Öğrenciler ortalama olarak bir kardeşe sahiptir ve öğrencilerin 5 tanesi ailenin ilk çocuğu olup kalan öğrenciler ailenin ikinci çocuğudur.

\section{Veri Toplama Araçları}

$\mathrm{Bu}$ bölümde araştırmaya ait nitel veri toplama araçlarına ilişkin detaylı bilgiye yer verilmiştir.

\section{Nitel Veri Toplama Araçları}

Demografik değişkenler: $\mathrm{Bu}$ kısım, anneye yöneltilen çocuğun yaşı ve cinsiyeti, çocuğun kardeş sayısı, çocuğun ailede kaçıncı çocuk olduğu ve sosyo-ekonomik seviye sorularını içermektedir.

Yaratıcılık: Torrance Yaratıcılık Testi (Torrance, 1974) ile ölçülen çocuklardaki yaratıcılık testinde, beyaz bir kâğı üzerinde 9 ayrı kutu içerisinde verilen farklı rasgele şekillerin her birinin üzerine çocuğun dilediği kadar süre içerisinde çizim yapmasını istenmektedir. Üretilen çizim Torrance'in yaratıcılık kriterleri (akıcılık, esneklik, orijinallik ve detaylandırma ana kriterlerinin alt kriterlerinden oluşan 10 kriter) üzerinden puanlanmıştır. Puanlama içerisinde her bir kriter en yüksek 5 puan üzerinden değerlendirilmekte ve toplam puan (en fazla 50 olmak üzere) öğrencilerin yaratıcılık puanlarını oluşturmaktadır (Torrance Yaratıcılık Testi literatürde bilimsel ya da sanatsal yaratıcılık ölçümü altında sınıflandırılmamıştır.)

Karmaşık çalışma belleği: Dinleme Aralığı Testi, Gaulin ve Campbell (1994) ile Pickering ve Gathercole (2001) tarafından geliştirilen ve çocuklarda karmaşı çalışma belleği becerilerini ölçebilen bir testtir (Gathercole, 1999). Testin Türkçe uyarlaması Ünal, Özge ve Marinis (2020) tarafindan gerçekleştirilmiştir ve testin Türk çocuklarında da karmaşık çalışma belleği becerilerini ölçebildiği bulunmuştur (Ünal, 2008). Testte, çocuklara tek tek kısa cümleler okunmaktadır. Çocuklardan öncelikle bu cümlelerin doğruluklarını "Evet/Hayır" diyerek belirtmeleri istenmekte, ardından da ilgili cümlenin son kelimesini söylemeleri beklenmektedir. Örneğin, ilgili cümle "Balıklar havada uçar." ise, çocuktan "Hayır, uçar." demesi beklenmektedir. Her bir cümle seti sonunda ise çocuktan tüm son kelimeleri sırası ile söylemesi istenmektedir. Cümle setindeki cümle sayısı, çocuk doğru cevap verdiği sürece 6'lık setlere kadar artabilmektedir. Bu testin için iki farklı puan hesaplanmaktadır. (i) toplam ulaşılan set sayısı (en fazla 6) ve (ii) toplam hatırlanan kelime sayısı (en fazla 120).

Öğrencinin motivasyonel eğilimleri hakkındaki görüşler: Çalışmaya katılan öğrencilerin motivasyonel eğilimlerini belirleyebilmek için nitel görüşme tekniği kullanılmıştır. Nitel görüşmelerde annelere ve öğrencilere ayrı ayrı yarı yapılandırılmış sorular yöneltilmiştir. Görüşme; genel olarak ebeveynlerin çocuklarının ders çalışma süreçlerinin zorlukları hakkındaki bilgilere ulaşmayı, bu süreçte çocukların kendilerini nasıl ödüllendirdiklerini ve bunun etkililiğini tespit etmeyi amaçlamaktadır. Ayrıca ebeveynin (ve varsa ailedeki diğer bireylerin) ve öğretmenin çocuğu ders çalışması için motive etme yöntemlerini ve bunların etkililiği hakkındaki bilgilere ulaşmayı ve son olarak da çocuğun motivasyonel yönelimi ve bu yönelimin etkililiği hakkındaki bilgilere ulaşmayı amaçlamıştır. 


\section{Verilerin Toplanması ve Analizi}

Araştırma, katılımcı ailelerin evlerinde bir görüşmeci tarafindan anne ve çocuk ile ayrı olmak üzere yürütülen görüşmeler ve testler üzerinden gerçekleştirilmiştir. Araştırmada annelere, çocuklarının kendilerini ders çalışmak ve sorumluluklarını yerine getirmek için nasıl motive ettikleri hususunda sorular yöneltilmiştir. Annelere ayrıca demografik sorular da yöneltilmiştir. Çalışmadaki öğrencilerle ise nitel görüşme gerçekleştirilmiş ve onlara bilişsel testler uygulanmıştır. Nitel görüşmede, bu öğrencilerin kendilerini ders çalışmaya nasıl motive ettikleri hususunda onlara sorular yöneltilmiştir. Buna ek olarak, çocuklara iki ayrı bilişsel test (Dinleme Aralığı Testi ve Torrance Yaratıcılık Testi) uygulanmıştır. Çalışmanın nitel kısmı içerik analizi yöntemi ile incelenmiştir ve elde edilen nicel veriler yalnızca nitel verileri yorumlama amacıyla kullanılmıştır. Çalışmanın hem ebeveyne hem de çocuğa uygulanması toplamda ortalama 1-2 saat civarında sürmüştür.

\section{Araştırma Etiği}

$\mathrm{Bu}$ araştırma için Ankara Yıldırım Beyazıt Üniversitesi Sosyal ve Beşerî Bilimler Etik Kurulundan 13.02.2019 tarihli ve 42 numaralı etik kurulu izni alınmıştır. Ayrıca, çalışmaya katılan yetişkinlerin kendilerinden, çocukların ise annelerinden yazılı onamları alınmıştır.

\section{Bulgular}

Bu bölümde, araştırma bulguları iki ana başlık altında ele alınmıştır: (i) motivasyon, ödül ve ders çalışabilmek ve (ii) bilişsel beceriler ve yaratıcılık.

\section{Motivasyon, Ödül ve Ders Çalışabilmek}

Çalışmanın nitel kısmındaki veriler incelendiğinde, birinci soru ("Çocuğunuz/Sizin için ders çalışmak zor mu? Zor ise ne kadar zor? Ders çalışma süreci çocuğunuz/sizin için nasıl kolaylaşabilir?") için hem veliler hem de öğrenciler, ders çalışmayla ilgili zorluğu belirli bir koşula bağlamışlardır. Koşula bağlı zorluk beyanı öğrencilerde altı kişi tarafından, velilerde ise beş kişi tarafından belirtilmiştir. Dört öğrenci tarafından ders çalışmanın zor olduğu belirtilmiş, iki öğrenci tarafından zor değil ama sıkıcı olduğu bildirilmiş, diğer bir kişi ise ders çalışmanın kolay olduğunu ifade etmiştir. Velilere bakıldığında ise üç veli ders çalışmanın çok zor olduğunu belirtmiş, bir katılımcının annesi ise durumu işkence ibaresi ile tarif etmiştir (bkz. V7). Durum ile ilgili olarak zor diyen velilerin sayısı iki, zor değil diyenlerin sayısı ise yine ikidir. Ders çalışmanın kolay olduğunu söyleyen öğrencinin (bkz. Ç3) velisi de ders çalışmanın kolay olduğunu söylemiştir ve bu çocukta içsel motivasyonun yüksek olduğu görülmektedir. Üstelik ailesi çocukta ödül-ders bağlantısını bilerek kurmadıklarını belirtmiştir (bkz. V3).

Birinci soru için en çok bahsedilen koşul, duygu durumdur. Bunlar can sıkıntısı, kişinin mutluluğu, o an nasıl hissettiği gibi durumlara işaret etmektedir. Duygu durumunun birinci soruda bütün katılımcılar tarafından dile getirilmesi, duyguların kişinin ders çalışması üzerindeki etkisinin önemini göstermektedir. Bunun haricinde ön plana çıkan bir diğer durum ise fiziki şartlar olmuştur. $\mathrm{Bu}$ fiziki şartlar arasında, çocuğun masasını ablasıyla paylaşmak zorunda olması, evde gürültü olması, okulda sınıfın kalabalık olması gibi durumlar belirtilmiştir (bkz. V2). Ders çalışmanın zorluğunu belirleyen başka koşullar ise, dersin zor ya da kolay olarak görülmesi, dersle ilgili soruların zor ya da kolay olması, dersi sevip sevmeme durumu ve o dersin öğretmenidir. Bunlar dışında ders çalışma isteğinden de ayrıca bahsedilmiştir.

Araştırmacı (A): Sizce çocuğunuz için ders çalışmak zor mu?

Veli (V): İskence.

A: Peki neden işkence olarak görüyorsunuz? Böyle düşünmenize neden olan bir şey var mı?

$V$ : Ders çalışmayı hiç sevmiyor, okulda dinlediğinin ona yettiğini düşünüyor. Öğretmenden öğrendiğinin ona yettiğini düşünüyor. 
A: Peki, yani çocuğunuz okuldan ögrendiğinin yeterli olduğunu düşündü̈̆̈̈ için fazladan ders çalışmayı zor görüyor.

V: Evet öyle, işkence geliyor ona. (V7)

Çocuk (Ç): (Yukarı doğru bakar) Ders çalışmak, çoğu zaman kolay. Ders çalışırken zevk alıyorum, kendimi motive etmiş oluyorum. Zor soruları yapabilince devamı da geliyor ve diğer soruları da basitçe yapabiliyorum. Böylece kendi kendimi motive etmiş oluyorum. Yani başardlkça motive oluyorum. (Ç3)

$V$ : Dersler konusunda biz, hiçbir zaman ödüllendirmedik. Ödevini bitirirsen sana şu ödülü vereceğiz demedik hiçbir zaman. Bu onun başarısıydl. Öte yandan kü̧̧ük de olsa istediği bir şeyi hemen yerine getirmeye çalışlyoruz; onu o şekilde motive etmeye çalışlyoruz. (V3)

$V$ : Bazen kafaya ne kadar uğraşsa da girmiyor, kendisini daha çok zorlaması gerekiyor ve zorlamıyor. Ablasıyla masa paylaşmak zorunda kaldiğı durumlarda daha zor olabiliyor. Televizyon ya da tablet gibi dikkat dağıtıcı unsurlar nedeniyle zorlaşabiliyor. (V2)

İkinci soruya ("Çocuğunuz/Siz ders çalışmak için kendisini nasıl gaza getirir/getirirsiniz? Kendisini/Kendinizi ödüllendirmek için neler yapıyor/yapıyorsunuz? Kendini ders çalışmak için nasıl motive ediyor/ediyorsunuz?") verilen cevaplarda en öne çıkan kategori, hem veli hem de öğrenciler için sosyal etkileşim/etkinlik olmuştur. Bu kategori içerisinde dışarıda arkadaşlarla oyun oynamak, aileyle beraber bir şeyler yapmak, sinemaya gitmek gibi unsurlar bulunmaktadır (bkz. Ç3). Öğrencilerin kendilerini motive etmeleriyle ilgili olarak bu kategoriden öğrenciler tarafindan $7 \mathrm{kez}$, veliler tarafından ise $4 \mathrm{kez}$ bahsedilmiştir. Bu durum, bize çocukların ders çalışmak için kendilerini en çok sosyal etkinlik ve etkileşim yoluyla motive ettiklerini göstermektedir. Bunun ardından en çok ön plana çıkan konu teknoloji olmuştur. Dört farklı öğrenci teknolojiye erişim için ders çalıştığını beyan ederken teknolojinin rolünden bahseden veli sayısı ise üçtür (bkz. V8). Ayrıca sosyal etkileşim ve teknoloji kategorilerinin hem öğrencilerde hem de velilerde ön plana çıkışı, tutarlılık açısından önemlidir.

Velilerde ve öğrencilerde ortaya çıkan diğer kategoriler daha tutarsızdır. Örneğin, dört öğrenci iyi not almanın kendilerini motive ettiğini söylemiş, üç tanesi yemek ile motive olduğunu belirtmiştir. Çocukların iyi bir gelecek elde etme arzusuyla çalıştığı konusu hem öğrencilerde hem de velilerde iki kez ön plana çıkmıştır. Üç tane veli çocuğunun kendisini motive etmediğini söylemiştir. Öne çıkan diğer bir önemli konu ise, ailenin çocuğa destek olmasının çocuğun kendisini motive etmesi hususunda önemli olduğudur. Öğrenciler ise stresten kurtulma isteğinin, ders çalışmayı kolaylaştıracak stratejiler geliştirmenin, arkadaşlar arasındaki rekabetin ve sözel ifadelerin kendilerini motive etmede önemli olduğunu dile getirilmiştir.

Ç: Oyun oynamayl, arkadaşlarımla gezmeyi severim. Bunun için de annemle anlaşma yaparız. Mesela ödevimi bitirip, kitabımı okuduktan sonra sevdiğim bu şeylerden birini yapacağıma dair bir anlaşma. Sonunda bir ödül olduğunu bildiğim için daha istekli yaparım. Bazen babamla eve gelirken radyoda bir şeyler dinlemek de beni motive ediyor. (Ç3)

$V$ : Bilgisayardan, internetten işin içinde teknolojik bir şey varsa buradan izliyorsa büyük bir zevkle izliyor. Teknolojinin içinde olması onu birazclk daha motive ediyor. Evet, o zaman daha güzel takip ediyor. Hani yanında oturmam gerekiyor, ben de oturup onunla birlikte incelemem lazım. Benim onunla birlikte izlemem lazım ama ben onun yanından kalkınca başka bir yere geçiş yapıyor hemen. (V8)

Görüşmedeki üçüncü soruda ise ("Çocuğunuzun/Kendinizin uyguladığı yöntemin ne kadar başarılı olduğunu düşünüyorsunuz? Çocuğunuzun/Kendinizin uyguladığı yöntem, onun/sizin ders çalışma performansını sizce ne kadar arttırıyor?’), sekiz çocuğa göre kendi uyguladıkları yöntem (en az kısmen olmak üzere) etkilidir. Ebeveynlerde ise yedi anne çocuklarının kullandıkları yöntemin bir şekilde etkili olduğunu, annelerden biri ise etkisiz olduğunu söylemiştir. Dört numaralı çocukta etkililik yalnızca sınıfta kalmamak için asgari notu alasıya kadardır ve bu beyan ebeveyn tarafından da doğrulanmıştır. Sekiz numaralı çocukta ise hem ebeveyn hem de aile, çocuk kendini motive etmek üzere bir yöntem kullanmadığı için etkililik hakkında bir şey söyleyemeyeceklerini beyan etmiştir. Beş numaralı çocuğun etkili olduğunu söylediği yöntem, oyun oynadıktan sonra ders çalışma yönündedir. 
$\mathrm{Bu}$ çocuğa göre, eğer böyle yapmazsa, abisi gibi sıkıntıdan ölür. Bu çocuğun beyanlardan anlaşıldığ1 üzere abisi çok çalışkandır. Ancak çocuğun ebeveyni çocuğun bu yöntemi bir bahane olarak kullandığını ve çocuğun yönteminin işe yaramadığını belirtmiştir.

Öğretmenlerin ders çalışmaları için öğrencileri nasıl motive ettikleri hususunda (Soru \#4), en çok ön plana çıkan kategori sözel ifade/övgü kategorisi olmuştur. Beşer öğrenci ve veli doğrudan öğretmenin öğrencileri motive ettiğini belirtmiş, ikişer öğrenci ve veli ise yine öğretmenin doğrudan motive etmediğini ya da stres yarattığını beyan etmiştir. Bir öğrenci ise, öğretmenin stres yaratmasına neden olan faktör konusunda rekabetin çok ön plana çıkarılması konusunu belirtmiştir.

Beşinci soruda ("Çocuğunuzu/Kendinizi ödüllendirmek için neler yapıyorsunuz? Ders çalışması/çalışmanız için onu/kendinizi nasıl motive ediyorsunuz? Onu/Kendinizi nasıl gaza getiriyorsunuz?") ise, çocukların kendilerini motive etmelerine benzer olarak, ailelerde de en çok ön plana çıkan unsur sosyal etkinlik kategorisi olmuştur (bkz. V2). Bunun yanında ailenin destek olmasının (beraber ders çalışma gibi) çocukların ders çalışma motivasyonunda önemli olduğu görülmüştür (bkz. Ç9). Hem velilerin hem çocukların en çok beyan ettiği yöntemlerden biri olarak, çocuğu disipline etmenin kullanıldığ 1 da görülmüştür. Bu kategori hem ödül-ceza bağlantısını net bir biçimde ortaya koyarak çocuğu ders çalışmaya teşvik etmeye hem de belirli bir disiplin süreci içerisinde çocuğun ders çalışmasının sağlanmasına işaret etmektedir (bkz. V2). Hem çocukta hem de velide sözel ifadenin ders çalışmak için motivasyon aracı olarak kullanıldığı görülmüş̧ür. Bu sözel ifadeler "yapabilirsin, başarabilirsin" gibi ifadelerdir. Yine hem aile hem çocuk tarafından, ailenin kıyas ve rekabeti ders çalışmaya motive etmek amacıyla kullandığ 1 beyan edilmiştir. Ancak genel olarak kıyas hoşnut olunmayan bir durum olarak değerlendirilmektedir (bkz. V7). Öne çıkan diğer faktörler, çocuğa maddi ödüllerin alınması ve teknolojiye erişimin sağlanması, ailenin çocuğa stres olacak faktörleri ortadan kaldırmasıyla uygun ortam oluşturmasıdır. İki öğrenci ise ailenin mutlu olmasının kendisini motive ettiğini söylemiştir ki bu diğerkâmlığa işaret etmektedir.

$V$ : Karne iyi gelirse tatile memlekete gitme, 90 altına inmezse sinemaya gitme gibi ödüller vererek. Aslında zaten gidilecek çocuk zaten götürülecek ancak çocuk bunu ödül olarak görsün ve bu şekilde motive olsun. Dersi bitirirse dışarı çıkabilir, ödevlerini yaparsa uyarı almadan rahatça oturabilir, TV izleyebilir. Arkadaşlarıyla oynamak da önemli bir motive kaynağı. Biraz tablet telefon oynamasina izin verilerek. (V2)

G: Başka neler yapıyorlar motive etmek için?

Ç: Sinav varsa taktik falan veriyorlar, konu anlatıyorlar.

G: Ailenle beraber çalı̧̧mak da seni motive ediyor öyle mi?

Ç: Evet. (Ç9)

$V$ : Çocuk oluşturulmuş kurallar çerçevesinde kendi işini kendi görüyor. Sistemi ben oluşturdum o yüzden etkili. Kurallar o sistemi etkili çalıştırıyor, sürekli evde olduğum için bu süreci kontrol edebiliyorum. (V2)

$V$ : Baba biraz dâhil. Sadece "yaparsın kızım" diyor. Babası kıyas yapıyor ve çocuk bundan hiç hoşlanmıyor. (V7)

Araştırmadaki altıncı soru için ("Sizin uyguladığınız yöntemin ne kadar başarılı, etkili olduğunu düşünüyorsunuz? Yönteminiz çocuğunuzun/sizin ders çalışma isteğini/isteğinizi ne kadar artırıyor? Çocuğunuzun/Sizin performansı/performansınızı ne kadar artırıyor?") altı öğrenciye göre ailenin yöntemi etkiliyken iki öğrenci ailenin yönteminin etkili olmadığını belirtmiştir. Ebeveynlerde ise dört ebeveyne göre ailenin kullandığı yöntem etkiliyken, üç ebeveyne göre etkisiz, iki ebeveyne göre ise etkili ama yetersizdir. Sekiz numaralı öğrenciye göre ailenin kullandığı bir yöntem yokken, bu öğrencinin ebeveynine göre kullanılan yöntem hiç etkili değildir.

Katılımcılara sorulan son soruya (Tüm bu yöntemleri ve sonuçlarını genel olarak düşündüğünüzde; çocuğunuzun/sizin ders çalışma hevesinin/hevesinizin artmasında ne tür ödüllerin daha etkili olduğunu düşünüyorsunuz? Ödül, çocuğunuzun/sizin kendinden mi/kendinizden mi yoksa dişarıdan mı olduğunda, çocuğunuzun/siz daha başarılı olduğunu/olduğunuzu düşünüyorsunuz?) üç öğrenci ve altı veli eğer motivasyon içsel olsaydı çocuklarının daha iyi çalışacaklarında hemfikir 
olmuşlardır. Bunun yanında dışsal olmalı diyen öğrenci sayısı iki, veli sayısı ise birdir. Bu durumda, genel olarak içsel olması gerektiği kanısının hâkim olduğu görülmüştür. Üç öğrenci ve iki veli ders çalışmada en etkili olan faktörün içsel olduğunu belirtmiştir. Diğer üç öğrenci ve iki veli ise, çocukların ders çalışmalarında en etkili olan faktörün dışarıdan gelen unsurlar olduğunu söylemiştir. Yarı yarıya etkili olduğunu söyleyen öğrenci sayısı bir, veli sayısı üçtür. Bunlar dışında öğrencilerde öne çıkan ve ders çalışmayı en çok etkilediği düşünülen diğer faktörler; öğretmen etkisi, maddi hediye, etkinlik, ailenin mutluluğu ve sözel yönergeler olmuştur. Velilerde diğer öne çıkan faktörler ise yine ailenin mutluluğu, etkinlik, öğretmen, yaparak öğrenme, disiplin ve maddi hediyedir. Bu kısımda göze çarpan husus, doğrudan ailenin mutluluğunun ve doğrudan disiplinin de az da olsa önem arz etmesidir.

Katılımcılardan içsel motivasyonu en yüksek olan çocuğun ebeveyni görüşmede çocuğu ders konusunda hiçbir zaman ödüllendirmediğini belirtmiştir. Ayrıca bu çocukta aile desteğinin çok yüksek olduğu görülmüştür. Çocuğa göre ders çalışmasına en çok etki eden durum ailenin mutluluk durumudur. İçsel motivasyonu en düşük olan ve dişsal motivasyonun aile tarafindan kurulmaya çalışıldığ 1 , ancak başarılı olunmayan çocukta ise, aile desteğinin bulunmadığı veya çok az olduğu görülmüştür. Ayrıca aile tarafından çocuğa ders çalışırsan oyun oyna gibi bir bağlantı kurulmaya çalışılsa da bu durum çocuk tarafından reddedilmektedir. Çocuğa göre ailesinin etkisi yoktur ve kendisinin işe yaramaz olduğunu düşünmektedir. Tersine abisi çok ders çalışmaktadır. Ancak ailenin kıyas ve eleştirilerinin çocukta aksi yönde sonuçlandığı anlaşılmaktadır. Ayrıca hem çocuğun hem ailenin belirttiklerine göre, öğretmen çocuk için aileye "yeterli, fazla zorlamayın" demiştir. Bütün bunlara rağmen, çocuk motivasyonun içsel olması gerektiği kanaatindedir. Çocuk olup bitenin farkındayken ailenin çocuklarına muamelesinin ters yönde olduğu görülmektedir. Bütün bu durumlar göz önünde bulundurulduğunda gerçekleştirilen nitel görüşmeden şu sonuçlar ön plana çıkmaktadır:

\section{Motivasyon Bütünlüğü}

Çocuğun motivasyonu çok farklı süreçlerin ve faktörlerin dâhil olduğu bir durumdur. Çocuğun zaten kendi içerisinde motive olup olmadığı, aile desteği, öğretmen desteği, dışsal ödüllerin etkisi, duygudurum etkisi, çocuğun ders çalışma sürecinin maddiyata bağlı hale getirilip getirilmediği, çocuğun motivasyonunu kötü yönde etkileyen bir sorun olup olmadığı faktörleri ön plana çıkan faktörler olmuştur. $\mathrm{Bu}$ motivasyon bütünlüğünü (kıyas gibi) olumsuz yönde etkileyecek faktörler ortaya çıktığında çocuğun da ders çalışmaya karşı kararları etkilenebilmektedir.

\section{Aile Desteği}

Araştırmanın sonuçlarına göre, ailenin her şeye rağmen arkasında olduğunu bilmek bir çocuk açısından önemlidir. Sadece anne değil, babanın da çocuğa destek veriyor olması çocuğun motivasyon bütünlüğünün sağlanmasında önemlidir.

\section{Çocuğun Derse Yönelik Tutumu ve Öğretmen Etkisi}

Çocuğa dersi sevdirmede ve çocuğun derse yönelik tutumunda öğretmen faktörü de çok önemlidir. Öğretmenin dersi farklı stratejilerle anlatması, çocuklara her daim destek olması ve ders çalışmada kolaylaştırıcı işlevde bulunması çocuğun motive olmasında ve başarısında etkilidir.

\section{Farkındalık ve Referans Farklılıkları}

Çocuk hem okulda hem de aile içinde olup bitenlerin farkındadır. Ancak aile ve çocuğun referansları farklı olabilir. Aileye göre çocuğa alınan şeyler onun ders çalışması için olabilirken çocuk bunları kendi içerisinde değerlendirerek böyle bir zorunluluğu kendisine atfetmeyebilir. Örneğin, ailenin sürekli maddi ödül alarak dışsal motivasyona daha çok bağladığ 1 çocuğun durumunda, ebeveyn ve çocuğun beyanları arasında tutarsızlıklar bulunmaktadır. Ebeveyne göre motivasyon içsel olması gerekirken, çocuğa göre dışsal olmalıdır. Çocuğa göre ailenin yaptıkları etkisizken, ebeveyne göre etkilidir. Yani aile motivasyonun içsel olması gerektiğinin farkındadır, ancak bunu çocuğa yansıtma 
şekilleri itibariyle çocuk dışsal motivasyona bağlı olmuş gibi görünmektedir. Bu durum ise ödül toleransına işaret etmektedir.

\section{Ödül Toleransı}

Ödül, tolerans geliştirilebilen bir şeydir. Kimi çocuğa göre ailenin mutluluğu bir ödül olabiliyorken kimi çocuğa göre yurt dışına seyahate gitmek ödül olabilir. Çocuklar verilen ödülleri büyütmek isteyebilir. Hatta ebeveynlerden birinin belirttiğine göre çocuğu kendisine "Ders çalışırsam bana şunu alır mısınız?” şeklinde ödül teklif edebilmektedir (bkz. V2).

\section{Karmaşı Durumlar ve Olumsuz Tavırlar}

Araştırmanın sonuçlarına göre, olumsuz tavırlar genelde çocukların zihninde ön plandadır ve eleştirel tutumlar çocukların motivasyon bütünlüğünü bozabilmektedir. Örneğin, katılımcı çocuklardan birinin durumunda, ebeveyne göre çocuğunun ders çalışmasını sağlamak için birçok motivasyon aracı sunulmaktadır. Görüşme sırasında özellikle annenin çocuk için epey çaba sarf ettiği anlaşılmıştır. Ailenin maddi durumu çok iyi, ebeveynlerin eğitim seviyesi yüksektir, ancak ailede karmaşık bir durum oluştuğu anlaşılmaktadır. Çocuğa göre ailenin sağladığı bir motivasyon aracı yokken, aileye göre bir motivasyon aracı olarak ortaya konulan birçok şey vardır. Yani, çocuk ortaya konulan şeyleri ders çalışmak için bir motivasyon aracı olarak görmemektedir. Üstelik çocuğa göre sözel yönergeler bile ders çalışmasında etkili olabilir, ancak aile tarafından o bile sunulmamaktadır. Yani, çocuk ve aile arasında ödül ve derse dair referans farklılıkları ve tutarsızlıklar bulunmaktadır. Bunun yanında çocuk babanın desteğini istemektedir, ancak babayla çocuk arasında iletişim sorunu yaşandığı anne tarafından ifade edilmiştir. Bunun nedeni olarak da geçmişteki bir takım ailevi sorunlar ön plana çıkmaktadır. Baba uzun bir müddet çocuğa karşı ilgisiz kalmış, ilgi göstermeye başladığında ise çocuğun tepkisi "Sen benimle şimdiye kadar hiç ilgilenmedin, şimdi ne alaka?" şeklinde olmuştur. Yine, ailenin ifadesine göre çocuk 8 yaşına kadar tek çocuktur ve ailenin belirttiğine göre, çocuğa fazla ilgi gösterilmiştir. Çocuk 11 yaşına geldiğinde kardeşi olmuştur ve ilgi bölünmüştür, çocuk yalnızca anne babası yanında olup ilgi gösterdiğinde ders çalışmaktadır. Bu katılımcı çocuk, öğretmenlerine göre de derslerinde çok başarılıdır, ancak sınav kâğıdına bu başarı yansımamaktadır. Anne bu durumu iyileştirmek için bir şeyler yapılması gerektiğini önerirken babanın durumu kestirip attı̆̆ını belirtmektedir (bkz. V8).

V: Ödüller klyaslanacak olursa somut ödüller verildiğinde ödülü büyütmek istenebiliyor, hatta çocuk gelip kendisi teklif edebiliyor, "Anne bu dersi çalışırsam bana şunu alır mısın?" diyebiliyor. Paralı ödül ve sosyal etkinlik karşılaştırllırsa sosyal etkinlik daha önemli ve uzun vadede etkili. Bir disiplin sağllyor. (V2)

V: En azından kesinlikle bir destek profesyonel bir destek almak şart gibi geliyor artık bana. Babamız ne gerek var, adam tembel işte diyor. Psikolojik desteğe ne gerek var diyor ama ben bir potansiyel olduğunu biliyorum, onu nasıl ortaya çıkaracağız, bunu bulmalıyız. (V8)

\section{Bilişsel Beceriler ve Yaratıcılık}

Araştırmada çocukların dinleme testi puanları, toplam ulaşılan set sayısı için 2,5-3 (6 üzerinden) arasında, toplam hatırlanan kelime sayısı ise 23-29 (120 üzerinden) arasında değişmektedir. Çocukların yaratıcılık puanları ise 4-19 (50 üzerinden) arasında değişmektedir.

Araştırma sonuçlarına bakıldığında, en yaratıcı olduğu belirlenen çocuğun motivasyon düzeyi diğer çocuklara göre en iyi durumdadır. Bununla beraber motivasyon açısından en düşük olan çocuğun yaratıcılığı da ikinci sıradadır. Bu durum bize yaratıcı olan bireylerin ders çalışma motivasyonu açısından çok düşük de olabileceğini göstermektedir. Bilişsel becerilerden dinleme aralığı testi sonucu en düşük olan çocuk hem aile hem de çocuğun motivasyonun dişsal olduğunu belirttiği ve hatta ikisinin de dışsal olması gerektiğini söylediği tek ailedir. 
Ayrıca, bir diğer anne düzenin kendi tarafından oluşturulduğu ve çocuğun bu düzen içerisinde kendi işini gördügünü ve bir disiplin içinde olduğunu belirtmiştir. Bu ailede çocuk ödevlerini yapmaktadır, ancak daha fazlası için çabalamamakta ve daha fazlası için motivasyonunun olmadığını ifade etmektedir. $\mathrm{Bu}$ hususta göze çarpan nokta ise, bu çocuğun yaratıcıllı̆ının ve bilişsel test sonucunun en düşük sonuçlardan biri olmasıdır.

Motivasyon seviyesi en düşük çocuklardan biri olan çocuk için ev içerisinde en elverişli koşulların sağlandığı anlaşılmaktadır. Anne çok çabalamaktadır ve öğretmenler çocukla ilgilenmektedir. Aynı zamanda, ailenin maddi seviyesi ve annenin eğitim seviyesi de yüksektir. Çocuk, dinleme aralığı testi sonucu en yüksek olan iki çocuktan biridir ve yaratıcilık testi sonucu da iyi düzeydedir. Ebeveyne göre, öğretmeni çocuğun derste iyi olduğunu söylemektedir. Ancak çocuk, bunu sınav kâğıdına yansitamamaktadır. Yine de ilgili öğrenci, motivasyon sıralaması olarak en düşük ikinci sıradadır. Bu durumla ilgili olarak şu nedenler ortaya koyulabilir: Çocuğa küçüklüğünde çok fazla ilgi gösterilmiştir ve çocuğun pek çok isteği yapılmaktadır. Çocuk, kardeşleri doğduktan sonra ilgi bölünmesi yaşamıştır ki kendisi bu durumun onu kötü etkilediğini belirtilmiştir. Birtakım sorunlardan sonra da çocuğun babasıyla arasındaki iletişim bozulmuştur. Bu durum, çoğu gerekli koşul sağlansa dahi birtakım olumsuzlukların çocuğu nasıl etkileyebileceğini göstermektedir.

Bu bağlamda, yaratıcılık seviyesi en yüksek olan çocuğun içsel motivasyon seviyesi de yüksek olduğu için araştırmanın hipotezi kısmen doğrulanmıştır. Ayrıca, bellek performansı en düşük olan çocuğun dışsal motivasyonunun yüksek ve içsel motivasyonunun düşük olması da yine araştırmanın hipotezini destekler niteliktedir. Fakat aynı hipotez motivasyon sıralamasında en düşük olan çocuğun yaratıcılığının da yüksek olması nedeniyle de kısmen doğrulanamamıştır.

\section{Sonuç, Tartışma ve Öneriler}

$\mathrm{Bu}$ araştırmanın amacı, yaratıcılık ile motivasyonun karmaşık bellek becerisi bağlamında incelenmesidir. Çalışmanın nitel sonuçlarına göre, ders çalışma hususu genel olarak hem anneler hem de çocuklar tarafından koşula bağlı bir şekilde zor olarak algılanmıştır. Bu zorluğun nedeni ise çoğunlukla duygu duruma atfedilmiştir. Yani, sonuçlar çocukların motive olma durumlarının onların duygulanımına göre değişebildiğini göstermektedir. Alanyazındaki çalışmalar, yaklaşma ve kaçınma motivasyonunun duygusal süreçlerde yer aldığını belirtmektedir. Bazı çalışmalar olumlu duygulanımı yaklaşma ve olumsuz duygulanımı ise kaçınma motivasyonu ile ilişkilendirse de (Watson, 2000), bu durumun tam tersi olması da mümkündür. Örneğin, öfke yaklaşma motivasyonu ile ilişkili olumsuz bir duygusal durumdur (Carver ve Harmon-Jones, 2009; Harmon-Jones, 2003). Bu bilgilerden yola çıkarak ders çalışma sürecinin işkence olarak görüldüğü bir çocuğun içinde bulunabileceği üzüntü duygusunun çocuğun kaçınma motivasyonunda bulunmasına, yani ders çalış(a)mamasına neden olabileceği söylenebilir.

Öte yandan, bu çalışmada hem katılımcı sayısı küçük bir örneklemi içermektedir, hem de nitel veriler kullanılmıştır. Bu nedenle çalışmanın sonuçları ilgili yaş grubundaki çocuklara genellenirken sınırlılıklara sahip olduğunu söylenebilir. Bir diğer sınırlılık ise, çalışmadaki ailelerin ve çocukların araştırmacıların sorularına (araştırmacıdan (ve/ya çocuk için aileden) çekinme, yanıtı aklına getirememe veya ilgili soruyu yeterince önemsememe gibi) bazı nedenlerden dolayı sorulara tam olarak yanıt verememesi olabilir. Son olarak, araştırmanın tek bir araştırmacı tarafından değil, farklı araştırmacılar tarafından yürütülmüş olması çalışmanın bir diğer sınırlılığı olarak değerlendirilebilir.

Çocuklar kendilerini sıklıkla sosyal etkileşim ve etkinliklerle motive ederlerken anneler de genel olarak bu görüşe katılmaktadır. Bu hususta, teknoloji kullanımı da (cep telefonu gibi) öne çıkan yöntemlerdendir. Ailelerinin yöntemlerini çocuklar genel olarak etkili bulurken anneler kendi yöntemlerini kısmen etkili bulmuştur. Çocuklar çoğunlukla kendi motivasyon yöntemlerinin başarılı olduğunu belirtirken annelerin bir kısmı çocukların yöntemini başarılı bulmakta, bir kısmı da ilgili yöntemi kısmen etkili olarak değerlendirmektedir. Ailelerin çocukları motive etme yöntemleri ise çoğunlukla etkinlikler üzerinden giderken çocukların bu durumla ilgili algıları; destek olma, sosyal etkinlik ve sözel ifadeler (aferin gibi) olarak sıralanabilir. Öğretmenlerin çocukları motive etme 
yöntemleri hususunda hem anneler hem de çocuklar çoğunlukla sözel ifade/övgü ve motive edici yaklaşım konusunda fikir birliğine varmışlardır. Ders çalışma motivasyonunda en etkili yöntem konusunda ise, çocuklar dişsal ödüller, içsel motivasyonun olması gerekliliği ve öğretmenin öneminden bahsederken, anneler ise çoğunlukla bu yöntemin içsel olması gerektiğinden bahsetmişlerdir. Ayrıca, bu konu ile ilgili farklı bir açıdan yaklaşarak ailenin mutluluğunu öne süren birkaç anne ve çocuk da bulunmaktadır.

Bilişsel kapasite (Simonton, 2010) ve çalışma belleği (Vandervert vd., 2007) görevlerini içeren karmaşık bellek testinde başarılı olan çocukların ayrıca yaratıcılıklarının da yüksek olması literatür ile uyum göstermektedir. Yaratıcılık bilişsel bir beceri olmasından ötürü (Sawyer, 2012), problem çözme sürecini içermektedir. Çocuklar yaratıcılıklarını sergilerken kendilerine has bir şekilde bilişsel becerilerini de kullanmaları gerektiği için çocukların bu becerilerinin de yeterli olması gerekmektedir (Shaffer ve Kipp, 2007).

Yaratıcılık ve bilişsel beceriler arasındaki ilişki değişken bir yapıya sahip olduğundan dolayı (Kim vd., 2010), bu çalışmanın bulguları da yine birçok değişkene (ebeveyn tutumları, bilişsel beceriler gibi) bağlı olarak farklılık göstermiş olabilir. Ayrıca kişilik ve çevresel faktörlerin de bu süreçte etkili olduğu söylenebilir (Simonton, 2000; Vandervert vd., 2007). Öğretmenin öğrencinin üzerindeki dolaylı fakat anlamlı motivasyon etkisi ise (Yuan, $\mathrm{Wu}, \mathrm{Hu}$ ve Lin, 2019) çalışma sonuçlarında kendisini ön plana çıkarmıştır. Bunlara ek olarak, dinleme aralığı testi hafizadaki yönetici işlevler tarafından yürütüldüğü (Pickering ve Gathercole, 2001) ve yaratıcılıkla ilişki bir değişken olduğundan dolayı (Benedek, Jauk, Sommer, Arendasy ve Neubauer, 2014; Beaty vd., 2014), aynı çizgide, bu çalışmada da dinleme aralığı testi bulgularının kısmen yaratıcılık skorları ile ilişkili olduğunu sonucu elde edilmiştir.

Yaratıcılığın gelişmesi için bir diğer değişken ise motivasyondur. Motivasyonla birlikte çocuklar yaptıkları işe daha iyi bir şekilde odaklanabilmekte (Myers, 2004) ve bu sayede yaratıcılıkları artabilmektedir. Ayrıca, motive olmuş çocuklar yapmaları gerekli olan davranışları dikkatlerini sürekli bir şekilde verebilirler ve odaklanabilirler (Fidan, 1986; Akt. Aktaş, 2016). Bu durumda da motivasyon çocukların bilişsel becerilerini (bellek, dikkat gibi) dolaylı olarak geliştirmelerini yardımcı olabilir.

Yönetici süreçler ve motivasyon hedefe yönelik davranışları belirleyen iki bileşendir (Szatkowska, Bogorodzki, Wolak, Marchewka ve Szeszkowski, 2008). Aynı zamanda, erken çocukluk döneminde motivasyon, daha sonraki bilişsel yetenekleri ve başarıyı öngörmektedir (Luster ve McAdoo, 1996). Motivasyon insan davranışının merkezinde yer almakta, verdiğimiz kararları, aradığımız deneyimleri ve dolayısıyla kodladığımız ve hatırladığımız şeyleri de etkilemektedir. Bununla birlikte, motivasyon her zaman daha iyi bellek performansı ile sonuçlanmayabilir. Daha ziyade motivasyon, bir davranışın nasıl teşvik edildiğine ve bireyin onu nasıl algıladığına bağlı olarak öğrenmeyi zayıflatabilir veya geliştirebilir (Murty ve Dickerson, 2016).

Bunlara ek olarak katılımcılardan bazı aileler çocuklarına ödüller sunduklarını belirtmişlerdir. Buna rağmen, bu ailelerin çocukları sunulan ödülü bir motivasyon aracı olarak kabul etmediği ve değerli görmediğinden, yani ödül ile yapılması gereken etkinliği (ders çalışmayı) eşleştirmediğinden (Eisenberger ve Selbst, 1994) bu çocuklar bilişsel beceriler ve/ya yaratıcılık alanlarında düşük performans sergileyebilmektedirler. Fakat, yine de alanyazına paralel bir şekilde, bu araştırmada da motivasyon seviyesi yüksek olan çocukların yaratıcılık seviyeleri genel olarak yüksek bulunmuştur (Hennessey, 2001; Isbell ve Raines, 2003).

$\mathrm{Bu}$ çalışma, çocuklarda yaratıcılık ile motivasyonun bilişsel beceriler çerçevesinde incelenmesini amaçlamış ve bu üç değişken birbiri ile ilişkili bulunmuştur. Bireyin hem kendi yaratıcılığını geliştirebileceği (Davis ve Rimm, 2004) hem de bu süreçte ailenin rolü (yaratıcılık için Miller vd., 2012; motivasyon için Tulunay-Ateş, 2016) düşünüldüğünde her yaştan çocuğun aile desteği ile birlikte kendi yaratıcı gücünün farkına varması önemlidir. Bu araştırmada yaşları 11 ile 13 arasında değişen çocuklar genel olarak her şeyi yaparak öğrenmeye (Çağatay-Aral, 1990) ve 
yaratıcılıklarını üst seviyelere taşımaya çalıştıkları için (Güleryüz, 2001), onları ailelerin desteğiyle birlikte yeni yaratıcı deneyimlerle buluşturmak önem arz etmektedir. Daha sonraki çalışmaların küçük şehirlerden katılımcılarla, farklı yöntemsel araçlarla (bilişsel yetenekler ve yaratıcılıkla ilgili farklı testlerle) ve/ya farklı türde (ek) değişkenlerle (oyun, farkındalık, akademik başarı, medya okuryazarlığı, kültür, cinsiyet gibi) yapılması önerilmektedir.

\section{Yazarların Katkı Oranı}

Bu çalışmada birinci yazarın \%45, ikinci yazarın \%30 ve üçüncü yazarın \%25 oranında katkıs1 bulunmaktadir.

\section{Çıkar Çatışması}

Bu çalışmada çıkar çatışması oluşturacak bir durum bulunmamaktadır.

Teşekkür: $\mathrm{Bu}$ araştırmadaki verilerin toplanmasında çok büyük emekleri geçen Firuze Ebrar Mullaoğlu, Fatma Gül Pemik, Gamze Taşkireç, Nursena Armağan, Ahsen Bahadır, Özge Karabulut ve Gökhan Karabulut'a en içten teşekkürlerimizi sunuyoruz.

\section{Kaynaklar}

Aktaş, N. (2016). Lise ögrencilerinin motivasyon kaynakları ve karar verme stratejileri. Yüksek lisans tezi. Adnan Menderes Üniversitesi, Sosyal Bilimler Enstitüsü, Aydın.

Argun, Y. (2004). Okul öncesi dönemde yaratıcılık ve eğitimi. Ankara: Anı Yayınc1lık.

Beaty, R. E., Silvia, P. J., Nusbaum, E. C., Jauk, E. and Benedek, M. (2014). The roles of associative and executive processes in creative cognition. Memory \& Cognition, 42(7), 1186-1197. doi: 10.3758/s13421-014-0428-8.

Benedek, M., Jauk, E., Sommer, M., Arendasy, M., and Neubauer, A. C. (2014). Intelligence, creativity, and cognitive control: The common and differential involvement of executive functions in intelligence and creativity. Intelligence, 46, 73-83. doi:10.1016/j.intell.2014.05.007

Bishop, D. W., and Chace, C. A. (1971). Parental conceptual systems, home play environment, and potential creativity in children. Journal of Experimental Child Psychology, 12(3), 318-338. https://doi.org/10.1016/0022-0965(71)90028-2

Carver, C. S., and Harmon-Jones, E. (2009). Anger is an approach-related affect: Evidence and implications. Psychological Bulletin, 135, 183-204. doi: 10.1037/a0013965

Chien, C.-Y., and Hui, A. N. N. (2010). Creativity in early childhood education: Teachers' perceptions in three Chinese societies. Thinking Skills and Creativity, 5(2), 49-60. https://doi.org/10.1016/j.tsc.2010.02.002

Çağatay-Aral, N. (1990). Alt ve üst sosyo-ekonomik düzeydeki dokuz yaş grubu kız ve erkek çocukların yaratıcılıklarını etkileyen bazı faktörler üzerine bir araştırma. Doktora tezi. Ankara Üniversitesi, Fen Bilimleri Enstitüsü, Ankara.

Çakmak, A. (2005). Anasınıfina devam eden altı yaşındaki köy ve kent çocuklarının yaratıcılıklarının çeşitli değişkenlere göre incelenmesi (Kırıkkale Örneği). Doktora tezi. Ankara Üniversitesi, Fen Bilimleri Enstitüsü, Ankara. 
Çolak, E. ve Cırık, İ. (2015). Ortaokul öğrencilerinin motivasyon kaynaklarının incelenmesi. Illkögretim Online, 14(4), 1307-1326. doi:10.1705/io.2015.08906

Davis, G., and Rimm, S. (2004). Education of the gifted and talented (5th ed.). Boston: Allyn and Bacon.

de Dreu, C. K. W., Nijstad, B. A., and Baas, M. (2011). Behavioral activation links to creativity because of increased cognitive flexibility. Social Psychological and Personality Science, 2(1), 72-80. https://doi.org/10.1177/1948550610381789

Deniş-Çeliker, H., Tokcan, A. ve Korkubilmez, S. (2015). Fen öğrenmeye yönelik motivasyon bilimsel yaratıc1lı̆̆ etkiler mi? Mustafa Kemal Üniversitesi Sosyal Bilimler Enstitüsü Dergisi, 12(30), 167-192.

Eisenberger, R., and Selbst, M. (1994). Does reward increase or decrease creativity? Journal of Personality and Social Psychology, 66, 1116-1127. https://doi.org/10.1037/00223514.66.6.1116

Feldhusen, J. F. (2005). Giftedness, talent, expertise, and creative achievement. In R. J. Sternberg, and J. E. Davidson (Eds.), Conceptions of giftedness (pp. 64-79). New York: Cambridge University Press. https://doi.org/10.1017/CBO9780511610455.006

Gathercole, S.E. (1999). Cognitive approaches to the development of short-term memory. Trends in Cognitive Sciences, 11, 410-419. https://doi.org/10.1016/S1364-6613(99)01388-1

Gaulin, C., and Campbell, T. (1994). Procedure for assessing verbal working memory in normal school-age children: some preliminary data. Perceptual and Motor Skills, 79, 55-64. doi:10.2466/pms.1994.79.1.55

Guilford, J. P. (1957). Creative abilities in the arts. Psychological Review, 64(2), 110-118. https://doi.org/10.1037/h0048280

Güleryüz, H. (2001). Eğitim programlarının dili ve yaratıcı ögrrenme. Ankara: Pegem Akademi Yayınc1lik.

Harmon-Jones, E. (2003). Anger and the behavioural approach system. Personality and Individual Differences, 35, 995-1005. https://doi.org/10.1016/S0191-8869(02)00313-6

Hennessey, B. A. (2001). The social psychology of creativity: Effects of evaluation on intrinsic motivation and creativity of performance. In S. Harkins (Ed.), Multiple perspectives on the effects of evaluation on performance: Toward an integration (pp. 47-75). Norwell, MA: Kluwer Academic. https://doi.org/10.1007/978-1-4615-0801-4_3

Isbell, R. T., and Raines S. C. (2003). Creativity and the arts with young children. Clifton Park, NY: Thomson/Delmar Learning.

Kampylis, P., Berki, E., and Saariluoma, P. (2009). In-service and prospective teachers' conceptions of creativity. Thinking Skills and Creativity, 4(1), 15-29. https://doi.org/10.1016/j.tsc.2008.10.001

Liang, J. C. (2002). Exploring scientific creativity of eleventh grade students in Taiwan (Unpublished Dissertation). University of Texas, Faculty of the Graduate School, USA. 
Luster, T., and McAdoo, H. (1996). Family and child influences on educational attainment: A secondary analysis of the High/Scope Perry preschool data. Developmental Psychology, 32, 26-39. https://doi.org/10.1037/0012-1649.32.1.26

Mansilla, V.B. (2010). Learning to synthesize: the development of interdisciplinary understanding. In R. Frodeman, K. J. Thompson, and C. Mitcham (Eds.), The Oxford handbook of interdisciplinarity (pp. 288-306). Oxford, UK: Oxford University Press.

Miller, A. L., Lambert, A. D., and Speirs-Neumeister, K. L. (2012). Parenting style, perfectionism, and creativity in high-ability and high-achieving young adults. Journal for the Education of the Gifted, 35(4), 344-365. https://doi.org/10.1177/0162353212459257

Murty, V. P., and Dickerson, K. C. (2016). Motivational influences on memory. In S. Kim, J. Reeve, and M. Bong (Eds.), Recent developments in neuroscience research on human motivation (Vol. 19, pp. 203-227). Bingley, UK: Emerald Group Publishing Limited. https://doi.org/10.1108/S0749-742320160000019019

Myers, D. G. (2004). Psychology (7th ed.). New York: Worth Publishers.

Ormrod, J.E., (2012). Human learning (6th ed.). USA: Pearson Education. Inc.

Ömeroğlu, E. ve Turla, A. (2001). Okul öncesi dönemde yaratıc1lık eğitimi ve desteklenmesi. Milli Ĕgitim Dergisi, 151, 49-53.

Park, N.K., Chun, M.Y., and Lee, J. (2016). Revisiting individual creativity assessment: Triangulation in subjective and objective assessment methods. Creativity Research Journal, 28(1), 1-10. https://doi.org/10.1080/10400419.2016.1125259

Park, S. B., and Yoon, J. L. (2004). The relationship between creativity, emotional intelligence, and academic achievements in the elementary school children. Journal of Educational Psychology, 18(4), 199-216.

Pickering, S. J., and Gathercole, S. E. (2001). Working memory test battery for children. London: Psychological Corp.

Rigby, C. S., Deci, E. L., Patrick, B. C., and Ryan, R. M. (1992). Beyond the intrinsic-extrinsic dichotomy: Self-determination in motivation and learning. Motivation and Emotion, 16(3), 165-185. https://doi.org/10.1007/BF00991650

Rotter, J. B. (1966). Generalized expectancies for internal versus external control of reinforcement. Psychological Monographs: General and Applied,80(1), 1-28. https://doi.org/10.1037/h0092976

Rowe, Alan J. (2007). Yaratıcı zekâ (Çev. Gülmen, Ş.). İstanbul: Prestij Yayınları. (Özgün çalışma, 2004).

Russ, S. W., and Fiorelli, J. A. (2010). Developmental approaches to creativity. In J. C. Kaufman, and R. J. Sternberg (Eds.), Cambridge handbook of creativity (pp. 233-249). New York, NY: Cambridge University Press. https://doi.org/10.1017/CBO9780511763205.015

Ryan, R. M., and Deci, E. L. (2000). Intrinsic and extrinsic motivations: Classic definitions and new directions. Contemporary Educational Psychology,25(1), 54-67. https://doi.org/10.1006/ceps.1999.1020 
Said-Metwaly, S., Van den Noortgate, W., and Kyndt, E. (2017). Approaches to measuring creativity: A systematic literature review. Creativity, Theories-Research-Applications, 4(2), 238-275. doi: 10.1515/ctra-2017-0013

Sawyer, R. K. (2012). Explaining creativity: The science of human innovation. New York: Oxford University Press.

Shaffer, D. R., and Kipp, K. (2007). Developmental psychology childhood and adolescence. Belmont: Thomson Higher Education.

Siegelman, M. (1973). Parent behavior correlates of personality traits related to creativity in sons and daughters. Journal of Consulting and Clinical Psychology,40(1), 43-47. doi: $10.1037 / \mathrm{h} 0033981$

Simonton, D. K. (2000). Creativity: Cognitive, personal, developmental, and social aspects. American Psychologist, 55(1), 151-158. https://doi.org/10.1037/0003-066X.55.1.151

Simonton, D. K. (2009). Creativity. Snyder, C. R., and Lopez, S. J. (Eds.), Oxford handbook of positive psychology (1st ed.) (pp. 189-202). Oxford Library of Psychology. doi:10.1093/oxfordhb/9780195187243.013.0024

Simonton, D. K. (2010). Creativity in highly eminent individuals. In J.C. Kaufman, and R.J. Sternberg (Eds.), The Cambridge handbook of creativity (pp. 174-188). New York, NY: Cambridge University Press. https://doi.org/10.1017/CBO9780511763205.012

Sternberg R.J. (2005). Creativity or creativities? International Journal of Human Computer Studies, $63,370-382$.

Szatkowska, I., Bogorodzki, P., Wolak, T., Marchewka, A. and Szeszkowski, W. (2008). The effect of motivation on working memory: An fMRI and SEM study. Neurobiology of Learning and Memory, 90(2), 475-478. https://doi.org/10.1016/j.nlm.2008.06.001

Torrance E.P. (1974). The Torrance tests of creative thinking: Technical-norms manual. Bensenville, IL: Scholastic Testing Services.

Torrance, E. P., Ball, E. O. and Safter, H. T. (1992). Torrance tests of creative thinking: Streamlined score guide figural A and B. Bensenville, IL: Scholastic Testing Service.

Tulunay-Ateş, Ö. (2016). Ortaokul öğrencilerinin algıladıkları sosyal destek ile motivasyon yönelimleri arasındaki ilişkinin yapısal eşitlik modeli ile incelenmesi. Kalem Eğitim ve İnsan Bilimleri Dergisi, 6(2), 357-386. doi: 10.23863/kalem.2017.65

Ünal, G. (2008). Release from proactive interference and its relations to executive functions: a developmental study on Turkish children (Unpublished master's thesis). Middle East Technical University, Graduate School of Informatics, Ankara.

Ünal, G., Özge, D. and Marinis, T. (2020). Assessing complex working memory in Turkish-speaking children: The Listening Span Task adaptation into Turkish. Frontiers in Psychology, 11, Article 1688, doi: 10.3389/fpsyg.2020.01688

Vandervert, L. R., Schimpf, P. H., and Liu, H. (2007). How working memory and the cerebellum collaborate to produce creativity and innovation. Creativity Research Journal, 19(1), 1-18. https://doi.org/10.1080/10400410709336873 
Vartanian, O. (2009). Variable attention facilitates creative problem solving. Psychology of Aesthetics, Creativity, and the Arts, 3(1), 57-59. https://doi.org/10.1037/a0014781

Yuan, Y. H., Wu, M. H., Hu, M. L. and Lin, I. C. (2019). Teacher's encouragement on creativity, intrinsic motivation, and creativity: The mediating role of creative process engagement. The Journal of Creative Behavior, 53(3), 312-324. https://doi.org/10.1002/jocb.181 


\section{Extended Abstract}

\section{Introduction}

Creativity differs depending on cognitive, personal and developmental differences (Simonton, 2000, 2009). These differences are also associated with many sub-basic elements such as family factors (Miller, Lambert, and Speirs-Neumeister, 2012). Another factor that is important in the cognitive and developmental process of the individual is motivation. The motivation could be observed frequently in creative individuals (Feldhusen, 2005; Hennessey, 2001; Isbell and Raines, 2003; Rowe, 2007). It is a concept that enables the individual to continue active in life and is divided into two as intrinsic and extrinsic. In the intrinsic motivation, the individual undergoes an intrinsically oriented motivation process without expecting an external reward. On the other hand, in extrinsic motivation, the individual acts with external rewards (Ormrod, 2012; Ryan and Deci, 2000).

Motivation, which is considered as one of the main variables in this study, can be seen frequently in creative individuals (Feldhusen, 2005; Hennessey, 2001; Isbell and Raines, 2003; Rowe, 2007). In addition, it was found that the external motivation of secondary school children differs according to the level of education, and the internal motivation differs according to the level of gender, education and academic success (Çolak and Curık, 2015). As children's motivation increases, their scientific creativity increases, as well (Deniş-Çeliker, Tokcan, and Korkubilmez, 2015). In line with this information, this study aims to examine the relationship between intrinsic and extrinsic motivation and creativity. The aim of this research is to examine the motivation processes of children in terms of themselves and their families in detail with their creativity and complex working memories. The hypothesis of the research is that creativity and complex memory levels of children with the high level of motivation will be high, as well.

\section{Method}

The study was carried out with the method of both qualitative interviews and quantitative data collection with nine volunteered parents and their children living in Ankara. In qualitative interviews, both the children and their parents were asked about children's internal and external motivation tools during studying their courses. It is also aimed to investigate how these tools are implemented by children, families, and teachers, and to investigate the effectiveness levels of these related tools. The quantitative materials of the study are complex working memory (Turkish Listening Span Test; Ünal, Özge, and Marinis, 2020) and Torrance test of creativity of children (Torrance, 1974).

\section{Findings}

According to the qualitative results of the study, studying was generally perceived as difficult in terms of conditions by both mothers and children. The reason for this difficulty is mostly attributed to emotional states. While children often motivate themselves with social interactions and activities, mothers generally agree with this view. In this regard, the use of technology is one of the prominent methods. While children often motivate themselves with social interactions and activities, mothers generally agree with this view. On the other hand, the children mostly state that their motivation methods are successful, although some of the mothers find the method of the children successful. Parents' methods of motivating children could be listed as support, social activity and verbal expressions. As for teachers' methods of motivating children, both mothers and children often agreed on the verbal expression/praise and motivating approach of the teachers. Regarding the most effective method of studying motivation, the children talked about external rewards, the necessity of internal motivation and the importance of the teacher, while the mothers mostly mentioned that this method should be intrinsic. In addition, there are several mothers and children on this issue who approached from a different perspective and put forward happiness of the family. 
Moreover, the Turkish Listening Span Test is carried out in order to measure executive functions in memory (Pickering and Gathercole, 2001) and the relationship of this test with creativity varies (Benedek, Jauk, Sommer, Arendasy, and Neubauer, 2014; Beaty, Silvia, Nusbaum, Jauk, and Benedek, 2014). This result is in the same line with the literature. In the study, it was concluded that the listening span test findings were partially related to creativity scores.

\section{Conclusion, Discussion and Recommendations}

The purpose of this research is to examine creativity and motivation in the context of complex working memory skills. The findings of this study may also differ depending on many variables (parental attitudes, cognitive skills, etc.), since the relationship between creativity and cognitive skills has a variable structure (Kim et al., 2010). The indirect but meaningful motivational effect of the teacher on the student (Yuan, $\mathrm{Wu}, \mathrm{Hu}$, and Lin, 2019) also highlighted itself in the results of the study. The Turkish Listening Span Test was carried out in order to measure executive functions in memory (Pickering and Gathercole, 2001) and since the relationship of this concept with creativity is varying (Benedek et al., 2014; Beaty et al., 2014), it was concluded that the findings of the listening span test were partially related to creativity scores.

Executive processes and motivation are two components that determine targeted behaviors (Szatkowska, Bogorodzki, Wolak, Marchewka, and Szeszkowski, 2008). It also predicts motivation, later cognitive abilities and success in early childhood (Luster and McAdoo, 1996). Motivation is very important for human behavior since it affects the decisions we make, the experiences we seek, and thus what we code and remember. However, motivation may not always result in better memory performance (Murty and Dickerson, 2016). Thus, like the results in the current study, the outcome may get affected according to the type of incentives and how these incentives are perceived by children (Eisenberger and Selbst, 1994).

Considering that the individual can both develop his own creativity (Davis and Rimm, 2004) and the role of the family in this process is important (for creativity, Miller et al., 2012; for motivation, Tulunay-Ateş, 2016), the family support of children of all ages becomes important, as well. It is suggested that future studies should be carried out with participants from small cities, with different methodological tools (different tests for cognitive abilities and creativity) and/or with different types of (additional) variables (such as play, awareness, academic achievement, media literacy, culture, and gender). 